\title{
Giant angioleiomyoma of uterus masquerading as ovarian tumour: a case report
}

\author{
Purnima Bhandari*, Anil C. Humane, Vaishali S. Deshmukh
}

Department of Obstetrics and Gynecology, Government Medical College and Hospital, Nagpur, Maharashtra, India

Received: 30 October 2019

Accepted: 05 December 2019

\section{*Correspondence:}

Dr. Purnima Bhandari,

E-mail: purnimabhandari9@gmail.com

Copyright: $\odot$ the author(s), publisher and licensee Medip Academy. This is an open-access article distributed under the terms of the Creative Commons Attribution Non-Commercial License, which permits unrestricted non-commercial use, distribution, and reproduction in any medium, provided the original work is properly cited.

\section{ABSTRACT}

Angioleiomyoma is a rare benign tumour of uterus. We are presenting an unusual case of 45 -year-old female with 11 $\mathrm{kg}$ giant angioleiomyoma of uterus which was masquerading as ovarian tumour on imaging. Exploratory laparotomy was done which was suggestive of huge lobulated mass arising from the uterus. Hysterectomy with bilateral salpingooophorectomy was done. Histopathological examination of specimen was suggestive of uterine subserosal and broad ligament angioleiomyoma of cavernous type. This case is being reported because of its rarity and challenges in diagnosis and management.

Keywords: Angioleiomyoma, Giant, Masquerading, Ovarian tumour, Rare, Uterus

\section{INTRODUCTION}

Angioleiomyoma is a benign mesenchymal neoplasm composed of smooth muscle cells and thick walled blood vessels. It originates from vascular smooth muscles. It frequently occurs in lower extremities. ${ }^{1}$ But angioleiomyoma of uterus is very rare. Worldwide very few cases of uterine angioleiomyoma have been reported till date. We came across a giant angioleiomyoma of uterus which was masquerading as ovarian tumour.

\section{CASE REPORT}

A 45 -year-old female, married since 26 years, para two live two, both full term normal vaginal deliveries, with bilateral tubal ligation done 22 years back, came with complaint of lump in abdomen since 6 months. She had no menstrual complaints. On examination, abdomen was distended and a large, firm mass of 36 weeks size felt per abdominally. On per vaginal examination, uterus was not palpable separately. Haemoglobin was $11.6 \mathrm{gm} \%$. Liver function test, kidney function test, serum electrolytes, INR were within normal limit. CA 125 was $10.27 \mathrm{kU} / \mathrm{l}$.
Ultrasonography was suggestive of a large $34.6 \times 15.1 \times$ $22.2 \mathrm{~cm}$ pelvic abdominal complex mass, appearing as cystadenocarcinoma of ovary. CT scan was suggestive of $31.3 \times 10.4 \times 21.6 \mathrm{~cm}$ solid cystic heterogeneous, mildly enhancing mass, involving pelvic-abdominal region possibly arising from bilateral adnexa with loss of fat plane with uterus at places, suggestive of ? mucinous cystadenocarcinoma of ovary. Ultrasonography guided FNAC of mass was done which was suggestive of no malignant cells in smears. Chest X-ray PA view and ECG were normal. Exploratory laparotomy was done that was suggestive of huge lobulated mass filling the whole abdomen and pelvis, and compressing the bowel upwards (Figure 1 and 2). Adhesions between the bowel and mass released by blunt and sharp dissection with the help of surgeon. Mass exteriorized and was arising from anterior, posterior and lateral walls of uterus. Bilateral ovaries and fallopian tubes were appearing normal. Course of bilateral ureters were traced and total abdominal hysterectomy with bilateral salpingooophorectomy was done. Specimen was weighing of 11 $\mathrm{kg}$. Intraoperatively, two units of whole blood were given. Histopathological examination of specimen was suggestive of uterine subserosal and broad ligament 
angioleiomyoma of cavernous type. Suture removal was done on postoperative day 14 and was healthy. Patient was stable and discharged on postoperative day 15 .

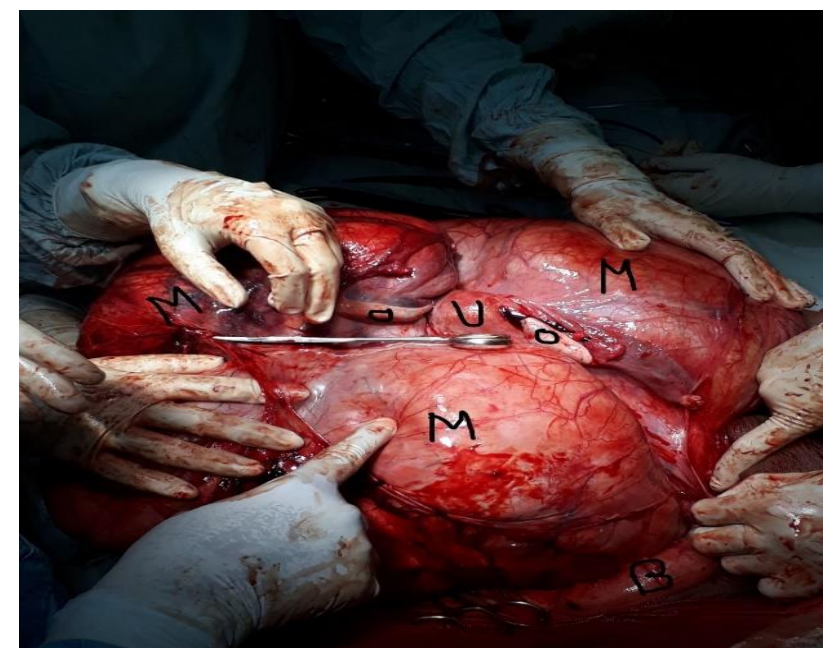

M: mass, U; uterus, O: ovary, B: bowel.

Figure 1: Intraoperative picture showing uterus, bilateral ovaries, a huge lobulated mass arising from anterior, posterior and lateral walls of uterus and bowel adherent to mass.

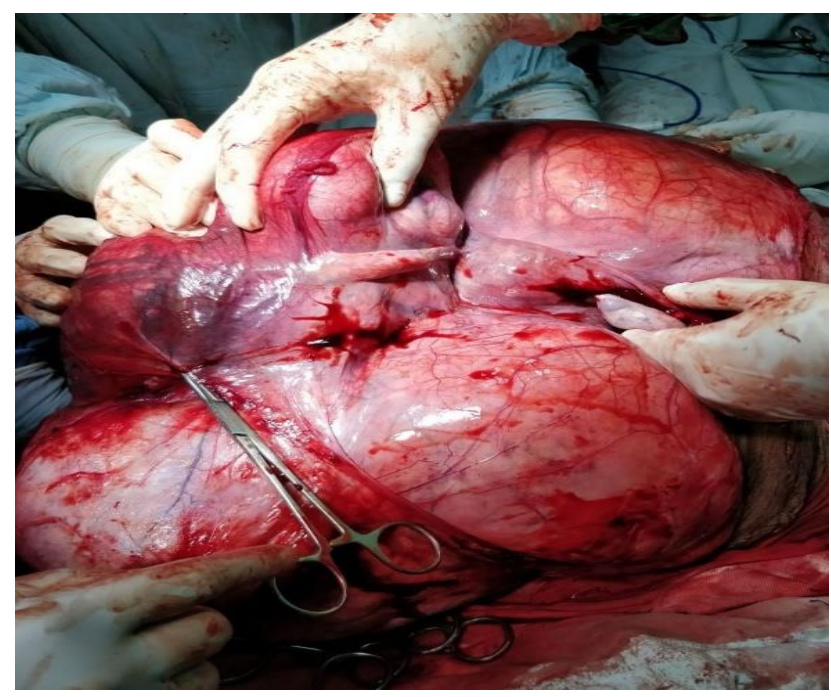

Figure 2: Intraoperative picture showing uterus, bilateral fallopian tubes, bilateral ovaries and a huge lobulated mass arising from anterior, posterior and lateral walls of uterus.

\section{DISCUSSION}

Angioleiomyoma occurs in $0.34-0.40 \%$ cases of uterine leiomyomas $^{1}$ It usually develops in middle aged women. $^{2,3}$ Patient in this case report, was of 45 years old. Patients with angioleiomyoma usually present with abdominal pain, menorrhagia, dysmenorrhoea, abdominal mass, severe anemia. ${ }^{2}$ In this case, patient was presenting with complaint of abdominal mass only. Other possible clinical findings reported in literature are consumptive coagulopathy, spontaneous rupture with abdominal bleeding, pseudomeig's syndrome and raised CA 125.4,5,6 Menorrhagia has been proposed due to dysregulation of growth factors like basic fibroblast growth factor and their receptors, which affect venous plexus in the leiomyoma and regulates the process of angiogenesis. ${ }^{7,8}$ Dysmenorrhoea results probably due to local ischemia from vessel contraction. ${ }^{4}$ Preoperative differentiation of angioleiomyoma from leiomyoma and ovarian neoplasm is very difficult- as was in this case. The ultrasonographic picture in most cases is indistinguishable from that of a conventional leiomyoma. ${ }^{2}$ Angioleiomyoma should be considered if CT scan reveals the presence of prominent tortuous vascular like enhancing structures in a well demarcated soft tissue mass arising from uterus. $^{7}$ However, preoperative diagnosis is not always possible as large sized lesions may be predominantly solid with loss of fat planes with uterine myometrium and it may be difficult to visualize the ovaries in these cases, thereby mimicking ovarian neoplasm- as was in this case. ${ }^{6}$ Gross picture mimics conventional leiomyoma except for the presence of blood filled spaces in angioleiomyoma. In all the cases reported so far, a definitive diagnosis was made only after histopathological examination of specimen - as was in this case. ${ }^{2}$ Histologically, angioleiomyoma can be classified into three subtypes-capillary or solid, cavernous and venous. ${ }^{9}$ In this case, it was of cavernous type. Treatment of choice is hysterectomy and if patient desires to preserve fertility angiomyomectomy should be done. ${ }^{10}$ While doing angiomyomectomy, capsule should be removed completely because of increased possibility of re-bleeding.

\section{Funding: No funding sources Conflict of interest: None declared Ethical approval: Not required}

\section{REFERENCES}

1. Weiss SW, Goldblum JR, editors. Benign tumors of smooth muscle. In: Enzinger and Weiss's Soft Tissue Tumors. $4^{\text {th. }}$ St. Louis, MO:The CV Mosby Co; 2001:699-700.

2. Garg G, Mohanty SK. Uterine angioleiomyoma: a rare variant of uterine leiomyoma. Arch Pathol Lab Med. 2014;138:1115-8.

3. Sharma C, Sharma M, Chander B, Soni A, Soni PK. Angioleiomyoma uterus in an adolescent girl: a highly unusual presentation. J Pediatr Adolesc Gynecol. 2014;27(3):e69-71.

4. Culhaci N, Ozkara E, Yüksel H, Ozsunar Y, Unal E. Spontaneously ruptured uterine angioleiomyoma. Pathol Oncol Res. 2006;12:50-1.

5. Handler M, Rezai F, Fless KG, Litinski M, Yodice PC. Uterine angioleiomyoma complicated by consumptive coagulopathy. Gynecol Oncol Case Rep. 2012;2(3):89-91.

6. Thomas S, Radhakrishnan L, Abraham L, Matthai A. Uterine angioleiomyoma with atypia, raised CA-125 
levels, and pseudo-Meigs syndrome: an alarming presentation. Case Rep Pathol. 2012;2012:519473.

7. Hsieh CH, Lui CC, Huang SC, Ou YC, Chang Chien $\mathrm{CC}$, Lan $\mathrm{KC}$, et al. Multiple uterine angioleiomyomas in a woman presenting with severe menorrhagia. Gynecol Oncol. 2003;90:348-52.

8. Stewart EA, Nowak RA. Leiomyoma-related bleeding: A classic hypothesis updated for the molecular era. Hum Reprod Update. 1996;2:295-306.

9. Hachisuga $\mathrm{T}$, Hashimoto $\mathrm{H}$, Enjoji $\mathrm{M}$. Angioleiomyoma. A clinicopathologic reappraisal of 562 cases. Cancer. 1984;54:126-30.
10. Zizi-Sermpetzoglou A, Myoteri D, Arkoumani E, Koulia K, Tsavari A, Alamanou E, et al. Angioleiomyoma of the uterus: report of a distinctive benign leiomyoma variant. Eur J Gynaecol Oncol. 2015;36:210-2.

Cite this article as: Bhandari $\mathrm{P}$, Humane $\mathrm{AC}$, Deshmukh VS. Giant angioleiomyoma of uterus masquerading as ovarian tumour: a case report. Int J Reprod Contracept Obstet Gynecol 2020;9:437-9. 